medRxiv preprint doi: https://doi.org/10.1101/2021.03.03.21252797; this version posted March 6, 2021. The copyright holder for this preprint (which was not certified by peer review) is the author/funder, who has granted medRxiv a license to display the preprint in perpetuity. It is made available under a CC-BY-NC-ND 4.0 International license .

\title{
Title: CNBP, REL, and BHLHE40 variants are associated with IL-12 and IL-10 responses and tuberculosis risk
}

Authors: Javeed A. Shah ${ }^{1,2}$, Alex J. Warr ${ }^{1}$, Andrew D. Graustein ${ }^{1,2}$, Aparajita Saha ${ }^{1}$, Sarah J. Dunstan $^{3}$, Nguyen T.T. Thuong ${ }^{4,5}$, Guy E. Thwaites ${ }^{4,5}$, Maxine Caws ${ }^{6}$, Phan V.K. Thai ${ }^{7}$, Nguyen D. Bang ${ }^{7}$, Tran T.H. Chau ${ }^{4}$, Felicia K. Nguyen ${ }^{1}$, Carlo A. Hernandez ${ }^{1}$, Madison A. Jones $^{1}{ }^{\text {, Christopher M. Sassetti }}{ }^{8}$, Katherine A. Fitzgerald ${ }^{8}$, Munyaradzi Musvosvi ${ }^{9}$, Anele Gela ${ }^{9}$, Willem A. Hanekom ${ }^{9}$, Mark Hatherill ${ }^{9}$, Thomas J. Scriba ${ }^{9}$, Thomas R. Hawn ${ }^{1}$.

Affiliations: ${ }^{1}$ University of Washington, Seattle, USA; ${ }^{2}$ VA Puget Sound Health Care System. Seattle, USA; ${ }^{3}$ University of Melbourne, Melbourne, Australia; ${ }^{4}$ Oxford University Clinical Research Unit, Ho Chi Minh City, Vietnam; ${ }^{5}$ Centre for Tropical Medicine and Global Health, Nuffield Department of Medicine, University of Oxford, Oxford, UK; ${ }^{6}$ Liverpool School of Tropical Medicine, UK; ${ }^{7}$ Pham Ngoc Thach Hospital, Ho Chi Minh City, Vietnam; ${ }^{8}$ University of Massachusetts, Worchester, MA., ${ }^{9}$ South African Tuberculosis Vaccine Initiative, Cape Town, South Africa

Correspondence: Javeed A. Shah; jashah@uw.edu. O: 206-543-8728; F: 206-339-1771

Author Contributions: Conceptualization: JAS, TRH, CS, KAF, SD, TS; Methodology: JAS, TRH, CS, TJS, SD; Validation: JAS, TRH, SD, TJS; Formal Analysis: JAS, TRH, SD, TJS, MH; Investigation: JAS, AJW, MJ, GPP, CH, AS; Resources: JAS, TRH, SD, MC, NTT, GT, TJS, MH; Writing - original draft preparation: JAS, $\mathrm{TRH}, \mathrm{MJ}, \mathrm{CH}$; Writing - editing and revising: JAS, AJW, MJ, CH, CS, KAF, TJS, MH, TRH; Visualization: JAS, MJ, TRH; Supervision: JAS, TRH, SD, TJS, NTT; Project Administration: JAS, TRH, CS, TJS, SJD; Funding Acquisition: JAS, TRH, CS, SD, TJS, MH.

Grant Support: R01 AI136921 to JAS; P01 AI132130 to CMS, TRH, JAS, SJD, TJS; K24 AI137310 to TRH; AI067497 to KAF.

Short Title: IL-10, IL-12, and TB

Descriptor Number: 10.6 Host Defenses to Microbial Pathogens

Total Word Count: 3332

This article has an online data supplement, which is accessible from this issue's table of content online at www.atsjournals.org. 
medRxiv preprint doi: https://doi.org/10.1101/2021.03.03.21252797; this version posted March 6, 2021. The copyright holder for this preprint (which was not certified by peer review) is the author/funder, who has granted medRxiv a license to display the preprint in perpetuity.

\section{It is made available under a CC-BY-NC-ND 4.0 International license.}

41

42

43

44

\section{1}


medRxiv preprint doi: https://doi.org/10.1101/2021.03.03.21252797; this version posted March 6, 2021. The copyright holder for this preprint (which was not certified by peer review) is the author/funder, who has granted medRxiv a license to display the preprint in perpetuity. It is made available under a CC-BY-NC-ND 4.0 International license .

2

45 Abstract

46 Rationale: The major human genes regulating M. tuberculosis (Mtb)-induced immune

47 responses and tuberculosis (TB) susceptibility are poorly understood. Although IL-12

48 and IL-10 are critical for TB pathogenesis, the genetic factors that regulate their

49 expression are unknown. CNBP, REL, and BHLHE40 are master regulators of IL-12 and IL-

5010 signaling.

51 Objectives: To determine whether common human genetic variation in CNBP, REL and

52 BHLHE40 is associated with IL-12 and IL-10 expression, adaptive immune responses to

53 mycobacteria, and susceptibility to TB.

54 Methods and Main Measurements: We characterized the association between common

55 variants in CNBP, REL, and BHLHE40 and innate immune responses in dendritic cells and

56 monocyte-derived macrophages (MDM), BCG-specific $T$ cell responses, and

57 susceptibility to pediatric and adult TB.

58 Results: SNP BHLHE40 rs4496464 was associated with increased BHLHE40 expression in

59 MDMs and increased IL-10 from both peripheral blood dendritic cells and MDMs after

60 LPS and TB whole cell lysate stimulation. SNP BHLHE40 rs11130215, in linkage

61 disequilibrium with rs4496464, was associated with increased BCG-specific IL2+CD4+ T

62 cell responses and decreased risk for pediatric TB in South Africa. SNPs REL rs842634

63 and CNBP rs11709852 were associated with increased IL-12 production from dendritic 
medRxiv preprint doi: https://doi.org/10.1101/2021.03.03.21252797; this version posted March 6, 2021. The copyright holder for this preprint (which was not certified by peer review) is the author/funder, who has granted medRxiv a license to display the preprint in perpetuity. It is made available under a CC-BY-NC-ND 4.0 International license.

3

64 cells, and SNP REL rs842618, in linkage disequilibrium with rs842634, was associated

65 with increased risk for TB meningitis.

66 Conclusions: Genetic variation in CNBP, REL, and BHLHE40 is associated with IL-12 and

67 IL-10 cytokine response and TB clinical outcomes. Common human genetic regulation of

68 well-defined intermediate cellular traits provides insights into mechanisms of TB

69 pathogenesis.

70 Abstract Word Count: 240

71 Keywords: CNBP, REL, BHLHE40, dendritic cells, genetics, M. tuberculosis 
medRxiv preprint doi: https://doi.org/10.1101/2021.03.03.21252797; this version posted March 6, 2021. The copyright holder for this preprint (which was not certified by peer review) is the author/funder, who has granted medRxiv a license to display the preprint in perpetuity. It is made available under a CC-BY-NC-ND 4.0 International license .

4

\section{Introduction}

73 Tuberculosis (TB) is a leading cause of death from infection worldwide. The

74 current BCG vaccine remains the only approved vaccine against TB despite its partial

75 and variable effects across populations (1). Vaccine efforts are hampered by a lack of

76 understanding of the immune correlates of protection (2). Understanding the factors

77 required to induce effective, long lasting immunity to infections may provide tools to

78 improve TB vaccines.

Twin, Mendelian, linkage, genome-wide association, and candidate gene studies

81 suggest that genetic factors influence susceptibility to TB $(3,4)$. Multiple clinical TB

82 phenotypes show a high degree of heritability, including host susceptibility to

83 pulmonary TB (5-10), TB meningitis $(11,12)$, and latent TB infection (13-17). However,

84 the major genes regulating TB susceptibility have not yet been identified with consistent

85 results across multiple populations, possibly due to heterogeneous clinical phenotypes

86 and lack of mechanistic correlation of genetic variants with immunophenotypes (3). To

87 overcome these obstacles, we evaluated LPS and Mtb whole cell lysate (TBWCL)-induced

88 cytokine responses from immune cells, followed by clinical correlation, to improve the

89 power and mechanistic insight of genetic studies.

90 
medRxiv preprint doi: https://doi.org/10.1101/2021.03.03.21252797; this version posted March 6, 2021. The copyright holder for this preprint (which was not certified by peer review) is the author/funder, who has granted medRxiv a license to display the preprint in perpetuity. It is made available under a CC-BY-NC-ND 4.0 International license .

5

Common genetic variation influences the cellular innate immune response to

92 Mycobacterium tuberculosis (Mtb). Multiple studies demonstrate the impact of genetic

93 variation on innate immune cellular distribution and cytokine responses (18-21).

94 Quantitative trait loci (QTL) of gene expression demonstrate immune cell-specific effects

95 (22). Recent advances permit the evaluation of innate immune cytokine responses from

96 rare cell populations $(23,24)$. Variants that influence functional responses in immune

97 cells of interest represent attractive secondary traits which can be correlated with TB

98 susceptibility and these correlations may provide insight into genetic mechanisms of

99 disease susceptibility (25).

100

101 Dendritic cells (DCs) present antigen to T cells via MHC Class I and II, co-stimulate

102 them with CD40 and CD80, and influence T cell differentiation by producing cytokines

103 like IL-12p70, IL-10, and IL-23, to induce T cell differentiation (26). DCs are essential for

104 mycobacterial immunity $(15,27)$ and common genetic variants that influence DC

105 migration are also associated with TB susceptibility (7). IL-10 and IL-12 are particularly

106 important for T cell function in Mtb infection. Individuals with Mendelian deficiencies in

107 IL-12 signaling rapidly develop serious, disseminated mycobacterial infections $(28,29)$.

108 However, the effect of common genetic variation on physiologic levels of IL-10 and IL-

109 12, and the influence of these cytokines on BCG-specific $\mathrm{T}$ cell responses and TB

110 outcomes in humans is not known. After inflammatory stimulation, the transcription 
medRxiv preprint doi: https://doi.org/10.1101/2021.03.03.21252797; this version posted March 6, 2021. The copyright holder for this preprint (which was not certified by peer review) is the author/funder, who has granted medRxiv a license to display the preprint in perpetuity. It is made available under a CC-BY-NC-ND 4.0 International license .

6

111 factor CNBP and its binding partner C-REL translocate to the nucleus and induce IL12B

112 transcription, which encodes the IL-12p35 protein subunit $(30,31)$. Likewise, IL-10

113 production influences Mtb immune responses, as it diminishes $\mathrm{T}$ cell activation,

114 enhances regulatory $\mathrm{T}$ cell activity, and may be responsible for delayed $\mathrm{T}$ cell priming

115 observed in the initial Mtb immune response $(32,33)$. In mice, the transcription factor

116 BHLHE40 controls IL-10 production from both myeloid and lymphoid cells, with

117 contribution from $\operatorname{CNBP}(30,31,34)$. The role of these genes and their genetic variants in

118 human regulation of T cell responses is unknown. In this study, we investigated whether

119 common human genetic variation in the transcription factors CNBP, REL, and BHLHE40

120 were associated with DC cytokine responses, BCG-specific $\mathrm{T}$ cell responses and TB

121 susceptibility.

123 Materials and Methods

124 Ethics Statement

125 Approval for human study protocols was obtained from the institutional review boards

126 at local sites and at the University of Washington School of Medicine (Seattle, WA). The

127 South African study included written informed consent from the parent or legal

128 guardian of the participant and approval by the University of Cape Town Research Ethics

129 Committee. Written informed consent was received from all participants before

130 inclusion in the study. For genetic studies in Vietnam, approval for human study 
medRxiv preprint doi: https://doi.org/10.1101/2021.03.03.21252797; this version posted March 6, 2021. The copyright holder for this preprint (which was not certified by peer review) is the author/funder, who has granted medRxiv a license to display the preprint in perpetuity. It is made available under a CC-BY-NC-ND 4.0 International license.

7

131 protocols was obtained from the human subjects review boards at the University of

132 Washington School of Medicine, the Hospital for Tropical Diseases, Pham Ngoc Thach

133 Hospital, Hung Vuong Hospital, and the Oxford Tropical Research Ethics Committee.

134 Written informed consent was obtained from patients or their relatives if the patient

135 could not provide consent.

136

137 Study Participants

138 Study participants in the Seattle cohort were volunteers self-described as healthy

139 without history of recurrent serious infections. $52 \%$ of individuals were female, and $48 \%$

140 were male. The ethnic composition of this study group was $69 \%$ White, $19 \%$ Asian, $2 \%$

141 Black or African American, and 2\% Latinx. Average age of study participants was 39, with

142 interquartile range of $29-46$ at the time of their enrollment.

South African study participants were enrolled at the South African Tuberculosis

145 Vaccine Initiative field site in Worcester, South Africa, near Cape Town as part of a larger

146 study on BCG vaccination with 11,680 infants $(35,36)$. This area has one of the highest

147 rates of TB in the world with an incidence of $3 \%$ among children less than 3 years of age

148 in the study population $(35,36)$. A nested genetics case-control study was performed

149 with identification of cases and controls during a 2-year prospective observation period 
medRxiv preprint doi: https://doi.org/10.1101/2021.03.03.21252797; this version posted March 6, 2021. The copyright holder for this preprint (which was not certified by peer review) is the author/funder, who has granted medRxiv a license to display the preprint in perpetuity. It is made available under a CC-BY-NC-ND 4.0 International license .

8

150 after vaccination at birth. The criteria for detection of TB cases have been described

151 previously and are summarized in the online supplement (37).

152

Study subjects from the Vietnam cohort were described previously and are

154 summarized here and in detail in the online supplement (12). Subjects with tuberculous

155 meningitis were recruited from two centers in Ho Chi Minh City, Vietnam: Pham Ngoc

156 Thach (PNT) Hospital for Tuberculosis and the Hospital for Tropical Diseases (HTD).

157 Subjects with pulmonary TB were recruited from a network of district TB control units

158 within Ho Chi Minh City that provide directly observed therapy to TB patients. In

159 addition, pulmonary TB subjects enrolled were recruited from PNT hospital from 2006

160 through 2008. Vietnamese population controls were otherwise healthy adults with

161 primary angle closure glaucoma which have been previously described (38). All case and

162 control participants were unrelated and greater than $95 \%$ were of the Vietnamese Kinh

163 ethnicity. Previous genetic studies of this population indicate minimal population

164 substructure $(12,39)$.

165

166

All statistical analyses are described in the online supplement and were

167 performed using Stata 14.1 and Prism 8.0 software. The remainder of all experimental

168 procedures are described in detail in the online supplement. 
medRxiv preprint doi: https://doi.org/10.1101/2021.03.03.21252797; this version posted March 6, 2021. The copyright holder for this preprint (which was not certified by peer review) is the author/funder, who has granted medRxiv a license to display the preprint in perpetuity. It is made available under a CC-BY-NC-ND 4.0 International license .

9

170

171

172

173

174

175

176

177

178

179

180

181

182

183

184

185

186 187 TBWCL and LPS stimulation (Figure 2A; $\mathrm{p}=0.044$, generalized linear model (GLM), 188 Figure 2B; $p=0.037)$. CNBP SNP rs11709852 was associated with increased IL-12

\section{Results}

Single cell analysis of cytokine production in peripheral blood DCs

To evaluate genetic regulation of IL-10 and IL-12 production from healthy human

donors, we used flow cytometry to measure the proportion of peripheral blood MHC-

II + CD11C + DCs producing IL-10 and IL-12 after stimulation of whole blood with LPS or

TB whole cell lysate (TBWCL; Figure 1A). LPS $(10 \mathrm{ng} / \mathrm{ml})$ and TBWCL $(50 \mu \mathrm{g} / \mathrm{ml})$ both strongly induced IL-12 (Figure 1B) and IL-10 (Figure 1C) from DCs 24 hours after stimulation. We also measured cytokine responses to LPS $(10 \mathrm{ng} / \mathrm{ml})$ and live BCG $\left(10^{6}\right.$ CFU/ml) 6 hours after stimulation (Figure 1D). We found that LPS and BCG induced IL-

126 hours after stimulation in CD11C+ DCs. However, we did not detect IL-10 above background levels from DCs after 6 hours of stimulation (data not shown).

Discovery analysis of genetic associations with $I L-12$ responses to $L P S$ and TBWCL. We next examined whether candidate gene variants were associated with LPS or TB whole cell lysate- (TBWCL) induced IL-12 in DCS. We interrogated 4 haplotypetagging SNPs from CNBP, 6 from REL, and 19 from BHLHE40 in a local cohort of healthy volunteers (Figure E1). REL SNP rs842634 was associated with increased IL-12 after 
medRxiv preprint doi: https://doi.org/10.1101/2021.03.03.21252797; this version posted March 6, 2021. The copyright holder for this preprint (which was not certified by peer review) is the author/funder, who has granted medRxiv a license to display the preprint in perpetuity. It is made available under a CC-BY-NC-ND 4.0 International license .

10

189 production after TBWCL stimulation, but not LPS stimulation (Figure 2C; $p=0.003$;

190 Figure 2D, $p=0.48$ ). No SNPs from BHLHE40 were associated with IL-12 (Table E2).

191

192 CNBP and REL variants are associated with LPS and BCG-induced IL-12 secretion after 6

193 hour stimulation in an independent dataset.

194 We evaluated the association of our candidate SNPs in a second, independent

195 cohort with whole blood stimulated with BCG $\left(10^{6} \mathrm{CFU} / \mathrm{ml}\right)$ or LPS (10 $\left.\mathrm{ng} / \mathrm{ml}\right)$ for 6

196 hours, followed by measurement of cytokine responses, as described above. REL SNP

197 rs842634 was associated with increased IL-12 after BCG infection (Figure 3A; $p=0.046$,

198 generalized linear model) and LPS stimulation (Figure 3B; $p=0.024$ ). CNBP SNP

199 rs11709852 was associated with a trend toward increased IL-12 after BCG stimulation

200 (Figure 3C; $p=0.078$, Mann-Whitney U-test), and was also associated with increased IL-

20112 after LPS stimulation early in infection Figure 3D; $p=0.014$, Mann-Whitney test).

202

203 BHLHE40 SNP rs4496464 is associated with IL-10 secretion from DCS

204 Next, we evaluated for associations between genetic variants in CNBP, REL, and

205 BHLHE40 with IL-10 production from DCs. BHLHE40 SNP rs4496464 was associated with

206 increased IL-10 production after TBWCL stimulation (Figure 4A; $p=0.005$, generalized

207 linear model). In contrast, rs4496464 was not associated with IL-10 after LPS stimulation

208 (Figure 4B, $\mathrm{p}=0.18$ ). No CNBP or REL SNPs, including rs11709852 and rs842634, were 
medRxiv preprint doi: https://doi.org/10.1101/2021.03.03.21252797; this version posted March 6, 2021. The copyright holder for this preprint (which was not certified by peer review) is the author/funder, who has granted medRxiv a license to display the preprint in perpetuity. It is made available under a CC-BY-NC-ND 4.0 International license .

11

209 associated with IL-10 expression after TBWCL or LPS stimulation. (Figure 4C - F).

210 BHLHE40 SNP rs4496464 was not associated with IL-12 expression after stimulation with

211 either TBWCL or LPS (Figure 4G and Figure 4H).

212

213 Rs4496464 is associated with BHLHE40 mRNA expression in monocyte-derived

214 macrophages

We evaluated whether rs4496464 genotypes were associated with BHLHE40

216 mRNA expression in peripheral blood monocyte-derived macrophages (MDM) from

217 healthy donors. The uncommon G allele of rs4496464 was associated with increased

218 BHLHE40 in unstimulated monocytes using a dominant model of inheritance (Figure 5;

$219 p=0.026, A / A$ vs $(G / A+G / G)$, Mann-Whitney U-test). No other BHLHE40 SNPs were

220 associated with expression. There was no association in LPS stimulated monocytes.

221 CNBP and REL variants were not associated with their respective transcripts (data not

222 shown).

223

224 Rs4496464 is associated with IL-10 production in LPS and TBWCL stimulated monocyte-

225 derived macrophages.

226 To validate our association between rs496464 and IL-10 expression in DCs, we

227 measured IL-10 secreted from monocyte-derived macrophages (MDMs) stimulated with

228 either LPS $(50 \mathrm{ng} / \mathrm{ml})$ or TBWCL $(25 \mu \mathrm{g} / \mathrm{ml})$ overnight (Figure $6 \mathbf{A}, \mathrm{n}=26)$. The rs4496464 
medRxiv preprint doi: https://doi.org/10.1101/2021.03.03.21252797; this version posted March 6, 2021. The copyright holder for this preprint (which was not certified by peer review) is the author/funder, who has granted medRxiv a license to display the preprint in perpetuity. It is made available under a CC-BY-NC-ND 4.0 International license .

12

229 G allele was associated with increased IL-10 after LPS stimulation (Figure 6B, $p=0.01$, 230 generalized linear model). SNP rs4496464 was also associated with increased IL-10 after

231 TBWCL (Figure 6C, $p=0.005$, generalized linear model). SNP rs4496464 was not

232 associated with TNF secretion after either LPS (Figure 6D) or TBWCL stimulation (Figure

233 6E), which suggests that variation in BHLHE40 is associated with IL-10 production

234 specifically, over proinflammatory cytokine responses.

235

236 A genetic marker for REL rs842634 is associated with an increased risk for TB meningitis.

237 Our data suggests that rs842634 and rs11709852 are associated with increased

238 IL-12 in DCs and rs4496464 is associated with increased IL-10 production from

239 peripheral blood monocytes and DCs in our local population. We hypothesized that

240 these polymorphisms are associated with susceptibility to TB due to their influence on

241 these critical immune phenotypes. Within a large genome wide association study

242 comparing Vietnamese individuals with adult pulmonary TB (PTB; $n=1598$ ) or TB

243 meningitis (TBM; $N=407)$ with control subjects $(N=1139)$, we evaluated if SNPs in

244 CNBP, REL, and BHLHE40 were associated with adult PTB or TBM and in LD with our

245 SNPs of interest (Figure E2). Although REL rs842634 was not associated with TBM, it was

246 in moderate to high LD with rs842618 in the Seattle cohort $\left(R^{2} 0.69, D^{\prime} 1.0\right)$ as well as in

247 the Vietnamese population $\left(R^{2} 0.39, D^{\prime} 1.0\right)$. The minor allele of REL SNP rs842618 was

248 associated with an increased risk for TBM ( $p=0.03$; OR 1.27, allelic model, Table 1 and 
medRxiv preprint doi: https://doi.org/10.1101/2021.03.03.21252797; this version posted March 6, 2021. The copyright holder for this preprint (which was not certified by peer review) is the author/funder, who has granted medRxiv a license to display the preprint in perpetuity. It is made available under a CC-BY-NC-ND 4.0 International license .

13

249 Table E3). These data best fit a dominant model (Table 1, $\mathrm{p}=0.035, \mathrm{OR} 1.32,95 \% \mathrm{CI}$

$2501.02-1.73$ ) No BHLHE40 or CNBP SNPs were associated with TBM, including rs4496464

251 and rs11709852. We did not identify any associations between SNPs in REL, CNBP, or

252 BHLHE40 SNPs with PTB (Table E4). Together, these data suggest that a causal REL

253 SNP linked to rs842634 and rs842618 is associated with both increased IL-12 production

254 and increased risk of adult TBM in Vietnam.

256 BHLHE4O variants are associated with pediatric TB in South Africa.

257 We next evaluated whether variants in CNBP, REL, and BHLHE40 were associated with

258 pediatric TB in South Africa (Figure E3) (40). BHLHE40 SNP rs11130215 was associated

259 with decreased risk for pediatric TB in an allelic model (Table 2 and Table E5; $p=0.001$ )

260 which best fit a dominant model of inheritance $p=3.3 \times 10^{-4}$, OR $0.5(0.33-0.75)$.

261 Rs11130215 was in low LD with rs4496464 in the South African cohort ( $\left.R^{2} 0.10, D^{\prime} 0.30\right)$.

262 To adjust for ethnic heterogeneity, we genotyped a panel of 95 ancestry informational

263 markers (AIMs) and performed principal components analysis, as described previously

264 (37). The association between rs11130215 and pediatric TB remained statistically

265 significant after adjustment for gender and the top five principal components of the

266 tested AIMs (Table 2, $p=0.01$, OR $0.24-0.83$ ). No REL or CNBP SNPs were associated

267 with pediatric TB, including rs842634 and rs11709852. Together, these data suggest that 
medRxiv preprint doi: https://doi.org/10.1101/2021.03.03.21252797; this version posted March 6, 2021. The copyright holder for this preprint (which was not certified by peer review) is the author/funder, who has granted medRxiv a license to display the preprint in perpetuity. It is made available under a CC-BY-NC-ND 4.0 International license .

14

a BHLHE40 polymorphism (rs11130215) linked to rs4496464 and increased IL-10

269 expression is associated with a decreased risk for pediatric TB.

271 CREL, CNBP and BHLHE4O SNPs are not associated with BCG-induced T cell responses in

272 South African infants.

274 responses as a possible mechanism of TB susceptibility due to DC regulation of T cell

275 responses. We tested this hypothesis in a cohort of South African infants that were

276 vaccinated with BCG at birth and whose BCG-specific CD4+ IL-2, TNF, and IFN $\gamma+T$ cell

277 responses were measured at 10 weeks of age by flow cytometry $(36,37)$ (Figure E4).

278 Overall media (Figure 7A), BCG-induced (Figure 7B), and SEB-induced (Figure 7C)

279 responses are shown. We evaluated the association between genetic variation in our

280 SNPs of interest: rs842634, rs11709852, rs4496464, and rs11130215, with the frequency

281 of BCG-induced IL-2, TNF, and IFN $\gamma$ in CD4+ T-cells. Rs11709852 and rs842634 were

282 monoallelic in the South African cohort and not analyzed further. Rs4496464 was

283 associated with a trend toward increased IL2+CD4+ T cell frequency after BCG re-

284 stimulation but this did not achieve statistical significance (Figure 7D, $p=0.15$,

285 generalized linear model). This SNP was not associated with TNF or IFN $\gamma$ frequency in

286 CD4+ T cells (Figure 7E-F). The G allele of BHLHE40 rs11130215 was associated with

287 increased frequency of BCG-specific IL2 + CD4 + cells (Figure 7G, $p=0.015$, generalized 
medRxiv preprint doi: https://doi.org/10.1101/2021.03.03.21252797; this version posted March 6, 2021. The copyright holder for this preprint (which was not certified by peer review) is the author/funder, who has granted medRxiv a license to display the preprint in perpetuity. It is made available under a CC-BY-NC-ND 4.0 International license .

15

288 linear model), but not TNF or IFN (Figure 7H-I). In a second validation cohort,

289 rs11130215 was associated with a trend toward increased IL-2 expression that did not

290 achieve statistical significance (Figure 7J, $p=0.06$, generalized linear model). However,

291 when these data were combined, we found that this SNP was associated with increased

292 IL-2 from CD4 + T cells (Figure 7K, $\mathrm{p}=0.006$, generalized linear model). Taken together,

293 these data suggest that a BHLHE40 variant is associated with increased IL-2-producing

294 CD4+ T cells, and decreased risk for pediatric TB in a genetic cohort of South African 295 infants.

297 Discussion

298 IL-12 and IL-10 are both essential for an effective host response to tuberculosis,

299 and overexpression of either cytokine can similarly lead to adverse outcomes. In this

300 paper, we found that variation in REL and BHLHE40, genes that directly influence

301 expression of these cytokines, is associated with secretion of IL-12 and IL-10,

302 respectively, from peripheral blood DCs using a flow cytometry-based assay. To our

303 knowledge, this assay has not been used previously to evaluate the genetics of DC

304 immune responses $(20,41)$. Related variants in REL were associated with increased

305 expression of IL-12 and also with increased susceptibility to TBM, and SNPs in BHLHE40

306 associated with increased IL-10 were also associated with decreased risk for pediatric TB. 
medRxiv preprint doi: https://doi.org/10.1101/2021.03.03.21252797; this version posted March 6, 2021. The copyright holder for this preprint (which was not certified by peer review) is the author/funder, who has granted medRxiv a license to display the preprint in perpetuity. It is made available under a CC-BY-NC-ND 4.0 International license .

16

307 These data represent the most comprehensive evaluation of the human genetic loci

308 associated with IL-10 and IL-12 production in TB pathogenesis.

311 We found BHLHE40 variants that were associated with increased IL-10 production in

312 myeloid cells after LPS and TB whole cell lysate stimulation. A variant in linkage

313 disequilibrium was also associated with increased BCG-specific IL-2+CD4+ T cells with

314 stable frequencies of TNF + and IFN $\gamma+$ CD4 + T cells in South African infants. Critically,

315 this variant was associated with decreased risk for developing pediatric TB. Canonically,

316 increased IL-10 is associated with increased differentiation of regulatory T cells (43),

317 which may delay the appropriate activation of effective adaptive immune responses to

318 Mtb (44). However, a balanced immune response with increased number of antigen-

319 specific $T$ cells overall is beneficial to preventing infection. The relatively modest

320 changes to the cytokine response associated with genotype may influence $\mathrm{T}$ cell

321 proliferation and differentiation to promote a balanced and effective $\mathrm{T}$ cell response

322 (45). Moreover, BHLHE40 also demonstrates direct effects on T cell function in murine

323 models, and may be an alternate mechanism for the phenotypes we observed (46). IL-10

324 decreases pathology that may promote effective Mtb control $(34,47)$. Our observations

325 are consistent with a model whereby modest increases in BHLHE40 are associated with

326 increased IL-10 in macrophages, expanded IL-2+CD4+ T cell responses, and protection 
medRxiv preprint doi: https://doi.org/10.1101/2021.03.03.21252797; this version posted March 6, 2021. The copyright holder for this preprint (which was not certified by peer review) is the author/funder, who has granted medRxiv a license to display the preprint in perpetuity. It is made available under a CC-BY-NC-ND 4.0 International license .

17

327 from TB. Notably, these data support findings from the mouse model, where BHLHE40

328 deficiency was associated with early Mtb death due to excessive neutrophil-dominant

329 inflammatory response (34). Study of the factors that influence IL-10 expression may

330 provide insight into a suite of macrophage or $\mathrm{T}$ cell changes that may provide insight

331 into TB susceptibility and control.

334 dendritic cells after LPS and TBWCL stimulation. A SNP in linkage disequilibrium,

335 rs842618, was also associated with increased risk for TB meningitis in a Vietnamese

336 cohort. Although IL-12 is canonically associated with protection from TB, significant

337 evidence has accumulated that increases in proinflammatory cytokines, including TNF

338 and IFN $\gamma$, may also be harmful for Mtb control in some settings, including TBM $(12,45$,

339 48). Although IL- $12 \alpha$ and IFN $\gamma$ are essential for control of Mtb infection, the amount

340 necessary for protection remains unclear (45). Excessive IFN $\gamma$ induces immune pathology

341 requiring anti-inflammatory therapy during TB immune reconstitution syndrome (49). IL-

34212 also induces TNF, in CD4 $+\mathrm{T}$ cells as part of the Th1 response (50). Excess TNF in

343 Mtb-infected macrophages leads to necrosis and Mtb spread, and worsens TBM

344 outcomes (51). Identification of genetic factors that modulate dendritic cell

345 proinflammatory cytokines provides insight into the optimal balance of cytokines to

346 control Mtb in adults. 
medRxiv preprint doi: https://doi.org/10.1101/2021.03.03.21252797; this version posted March 6, 2021. The copyright holder for this preprint (which was not certified by peer review) is the author/funder, who has granted medRxiv a license to display the preprint in perpetuity. It is made available under a CC-BY-NC-ND 4.0 International license .

18

This study has several potential limitations. We do not yet have evidence of

349 functional SNPs that directly regulate gene function. Future fine-mapping studies with in

350 vitro mechanistic assays will be required to determine the specific alleles that regulate

351 cellular function and clinical outcomes together. A second limitation is that some of

352 these observations do not achieve statistical significance after adjustments for multiple

353 comparisons with associations with clinical outcomes. Although this limitation is true for

354 the clinical findings, the evidence supporting a genetic regulatory role of human cellular

355 IL12/IL10 responses was robust and provided support for the possible clinical

356 associations. Given this, we used a threshold of $p<0.05$ as a measure of statistical

357 significance, without the conservative Bonferroni correction. Further studies will be

358 needed in additional cohorts, particularly after discovery of the causal SNP that

359 regulates cytokine production. Third, case-control studies of TB outcomes may have

360 misclassification of controls, as we examined population controls in studies in our

361 Vietnamese cohort. However, classification errors that arise from such control

362 populations likely lead to reduction in the statistical power of these studies.

363

364 To our knowledge, this study represents the most comprehensive analysis to date

365 of genetic regulation of dendritic cell IL-12 and IL-10 production by common

366 polymorphisms and their association with TB outcomes. Although further studies are 
medRxiv preprint doi: https://doi.org/10.1101/2021.03.03.21252797; this version posted March 6, 2021. The copyright holder for this preprint (which was not certified by peer review) is the author/funder, who has granted medRxiv a license to display the preprint in perpetuity. It is made available under a CC-BY-NC-ND 4.0 International license.

19

367 required, overlapping genetic studies of immune outcomes and TB clinical susceptibility

368 may lead to important breakthroughs in TB vaccine design and immune drug

369 development.

370

371 Acknowledgements

372 The authors thank the individuals and families who participated in the study. They also

373 thank the immunology and clinical teams at the hospitals in Ho Chi Minh City, Vietnam

374 and Worcester, South Africa for obtaining informed consent and collecting and

375 processing samples from study participants. They acknowledge the support of the

376 Center for Emerging and Reemerging Infectious Disease Flow Cytometry Facility at the

377 University of Washington. 
medRxiv preprint doi: https://doi.org/10.1101/2021.03.03.21252797; this version posted March 6, 2021. The copyright holder for this preprint (which was not certified by peer review) is the author/funder, who has granted medRxiv a license to display the preprint in perpetuity. It is made available under a CC-BY-NC-ND 4.0 International license .

20

378

379

380

381

382

383

384

385

386

387

388

390

391

392

393

394

395

396

397

\section{Figure Legends}

Figure 1. IL-10 and IL-12 responses in peripheral blood DCs in whole blood stimulation assay

Peripheral whole blood was obtained from healthy volunteers and stimulated with either negative control or immune stimuli followed by BFA and monensin 2 hours afterward. Afterward cells were fixed and frozen. At the time of staining, samples were thawed in large batches to minimize batch effects. A) Gating strategy. From left to right, singlets were selected, then leukocytes. CD66+ cells were gated out, and the HLA-DR+ population selected. CD14- and CD16- and CD11c+ cell population was selected and the proportion of cytokine positive cells were measured as compared to total number of $\mathrm{HLA}-\mathrm{DR}+\mathrm{CD} 11 \mathrm{c}+\mathrm{DCs}$

B) Proportion of IL-12+CD11c+ DCs after media control, LPS (10 ng/ml), or Mtb whole cell lysate (TBWCL; $50 \mu \mathrm{g} / \mathrm{ml}$ ) stimulation for 24 hours.

C) Proportion of IL-10+CD11C+ DCs after media, LPS, or TBWCL for 24 hours.

D) Proportion of IL-12+CD11C+ DCs after media, LPS, or live BCG $\left(10^{6} \mathrm{CFU}\right)$ stimulation for 6 hours. Bars demonstrate median values. Data provided are not corrected for background cytokine positivity. Dots represent individual values. $\mathrm{N}=46$.

Figure 2. REL SNP rs842634 and CNBP SNP rs11798052 are associated with IL-12 production after TBWCL stimulation of peripheral blood DCs for 24 hours 
medRxiv preprint doi: https://doi.org/10.1101/2021.03.03.21252797; this version posted March 6, 2021. The copyright holder for this preprint (which was not certified by peer review) is the author/funder, who has granted medRxiv a license to display the preprint in perpetuity. It is made available under a CC-BY-NC-ND 4.0 International license .

21

398 A-B) Proportion of CD11C+ DCs producing IL-12 after A) Mtb whole cell lysate (TBWCL;

$39950 \mu \mathrm{g} / \mathrm{ml})$ stimulation or B) LPS (10 $\mathrm{ng} / \mathrm{ml})$ stimulation for 24 hours. Data are stratified

400 by rs842634 genotype; $\mathrm{N}=19 \mathrm{~T} / \mathrm{T}, 21 \mathrm{~T} / \mathrm{C}$, and $7 \mathrm{C} / \mathrm{C}$.

401 C-D) Proportion of CD11C+ DCs producing IL-12 after C) TBWCL or D) LPS stimulation 402 for 24 hours. Data are stratified by rs11798052 genotype; $N=34$ G/G, 5 G/A, and 2 A/A.

403 All data presented in this figure and afterward represent background-corrected values 404 (proportion of cytokine-producing cells after ligand stimulation - proportion of 405 cytokine-producing cells after media control stimulation).

$406 * p<0.05$; statistical significance determined by generalized linear model.

408 Figure 3. REL SNP rs842634 is associated with IL-12 production in peripheral blood 409 DCs after 6 hours of BCG or LPS stimulation

410 A-B) Proportion of $\mathrm{CD} 11 \mathrm{C}+\mathrm{DCs}$ producing IL-12 after A) live BCG stimulation ( $10^{6} \mathrm{CFU}$ )

411 or B) LPS (10 ng/ml) stimulation for 6 hours. Data are stratified by rs 842634 genotype; $\mathrm{N}$ $412=15 \mathrm{~T} / \mathrm{T}, 16 \mathrm{~T} / \mathrm{C}$, and $4 \mathrm{C} / \mathrm{C}$.

413 C-D) Proportion of $\mathrm{CD} 11 \mathrm{C}+$ DCs producing IL-12 after C) live BCG stimulation or D) LPS 414 stimulation for 6 hours. Data are stratified by rs11798052 genotype; N = 31 G/G, 5 G/A.

$415{ }^{*} p<0.05 ;{ }^{* *} p<0.01,{ }^{* * *} p<0.001$; statistical significance determined by generalized 416 linear model for A-B and Mann-Whitney U-test for C-D. 
medRxiv preprint doi: https://doi.org/10.1101/2021.03.03.21252797; this version posted March 6, 2021. The copyright holder for this preprint (which was not certified by peer review) is the author/funder, who has granted medRxiv a license to display the preprint in perpetuity. It is made available under a CC-BY-NC-ND 4.0 International license .

22

418 Figure 4. BHLHE40 SNP rs4496464 is associated with IL-10 production from 419 peripheral blood DCs after Mtb whole cell lysate stimulation

420 A-B) Proportion of $\mathrm{CD} 11 \mathrm{C}+\mathrm{DCs}$ producing IL-10 after A) Mtb whole cell lysate (TBWCL;

$42150 \mu \mathrm{g} / \mathrm{ml})$ or B) LPS (10 $\mathrm{ng} / \mathrm{ml})$ stimulation for 24 hours. Data are stratified by rs4496494

422 genotype; $N=40$ A/A, 7 G/A and 2 G/G.

423 C-D) Proportion of CD11C+ DCs producing IL-10 after C) LPS or D) TBWCL stimulation

424 for 24 hours. Data are stratified by rs11798052 genotype; $N=33$ G/G, 5 G/A, and 2 A/A.

425 E-F) Proportion of CD11C+ DCs producing IL-10 after E) LPS or F) TBWCL stimulation for

42624 hours. Data are stratified by rs842634 genotype; $n=19 \mathrm{~T} / \mathrm{T}$ genotype, $21 \mathrm{~T} / \mathrm{C}$ 427 genotype, and 7 C/C genotype.

428 G-H) Proportion of CD11C+ DCs producing IL-12 after E) TBWCL or F) LPS stimulation

429 for 24 hours. Data are stratified by rs4496494 genotype. $N=38$ A/A, 7 G/A, 2 G/G.

$430{ }^{*} \mathrm{p}<0.05 ;{ }^{* *} \mathrm{p}<0.01,{ }^{* * *} \mathrm{p}<0.001$; generalized linear model.

432 Figure 5. BHLHE40 SNP rs4496464 is associated with increased BHLHE40 mRNA

433 expression in monocyte-derived macrophages

434 BHLHE40 mRNA expression, normalized to GAPDH expression, was measured from RNA

435 extracted from MDMs isolated from healthy volunteers and stratified by rs4496464; $\mathrm{n}=$ $43626 \mathrm{~A} / \mathrm{A}, 7 \mathrm{G} / \mathrm{A}$, and $1 \mathrm{G} / \mathrm{G} .{ }^{*} \mathrm{p}<0.05$; dominant genetic model. 
medRxiv preprint doi: https://doi.org/10.1101/2021.03.03.21252797; this version posted March 6, 2021. The copyright holder for this preprint (which was not certified by peer review) is the author/funder, who has granted medRxiv a license to display the preprint in perpetuity. It is made available under a CC-BY-NC-ND 4.0 International license .

23

438 Figure 6. BHLHE40 SNP rs4496464 is associated with IL-10 production from

\section{9 monocyte-derived macrophages}

440 Peripheral blood monocytes were differentiated into macrophages by M-CSF for 5 days,

441 then stimulated with either LPS (50 ng/ml) or Mtb whole cell lysate (TBWCL; $25 \mu \mathrm{g} / \mathrm{ml}$ ).

442 A) Overall IL-10 cytokine concentrations from cellular supernatants MDMs after 24 hours

443 of stimulation.

444 B-C) Concentration of IL-10 in cellular supernatants after B) LPS stimulation or C) TBWCL

445 stimulation for 24 hours, stratified by rs4496494 genotype. $N=20$ A/A, 6 G/A, 2 G/G.

446 D-E) Concentration of TNF in cellular supernatants after D) LPS stimulation or E) TBWCL

447 stimulation for 24 hours and stratified by rs4496464.

$448 * \mathrm{P}<0.05,{ }^{* *} \mathrm{P}<0.01,{ }^{* * *} \mathrm{P}<0.001$; generalized linear model.

Figure 7. BHLHE40 SNP rs11130215 is associated with BCG-induced IL-2+CD4+ T-

452 BCG-specific CD4+ T cell responses from South African infants at 10 weeks of age were

453 measured by flow cytometry and stratified by genotype of interest. Background

454 correction was performed by subtracting the proportion of cytokine-producing cells

455 after BCG or SEB stimulation from media control stimulation.

456 A-C) A) Media control, B) BCG-induced, and C) staphylococcus enterotoxin B (SEB)-

457 induced IL-2, TNF, and IFN $\gamma+$ CD4+ T cell responses. $\mathrm{N}=88$. 
medRxiv preprint doi: https://doi.org/10.1101/2021.03.03.21252797; this version posted March 6, 2021. The copyright holder for this preprint (which was not certified by peer review) is the author/funder, who has granted medRxiv a license to display the preprint in perpetuity. It is made available under a CC-BY-NC-ND 4.0 International license.

24

458 D-F) We measured the frequency of BCG-specific D) IL-2+, E) TNF+, and F) IFN $\gamma+$ CD4+ 459 T cells after 12 hours of re-stimulation and stratified by rs4496464. A/A N = 29, G/A N = $46044, \mathrm{G} / \mathrm{G} \mathrm{N}=11$.

461 G-I) We measured the frequency of BCG-specific G) IL-2+, H) TNF+, and I) IFN $\gamma+$ CD4+ T 462 cells after 12 hours of re-stimulation and stratified by rs 11130215 in a discovery cohort. $463 \quad A / A N=24, G / A N=31, G / G N=19$.

464 J) Proportion of BCG-specific IL-2+CD4+ T cells, stratified by $\mathrm{rs} 11130215$, in an 465 independent validation set. $A / A N=26, G / A N=47, G / G N=20$.

466 K) Combined datasets from D) and I).

467 All data visualized as Tukey plots, with middle bar representing median, thick bars with 468 interquartile range, and whiskers drawn to $10-90^{\text {th }}$ percentile. Outliers are represented 469 with dots. ${ }^{*} p<0.05,{ }^{* *} p<0.01$, generalized linear model. 
medRxiv preprint doi: https://doi.org/10.1101/2021.03.03.21252797; this version posted March 6, 2021. The copyright holder for this preprint (which was not certified by peer review) is the author/funder, who has granted medRxiv a license to display the preprint in perpetuity. It is made available under a CC-BY-NC-ND 4.0 International license.

472 Table 1. Association of REL SNPs with adult TB meningitis in Vietnam. Number of

473 individuals with major homozygous (AA), heterozygous (Aa), and minor homozygous

474 (aa) genotypes described. Total: total $\mathrm{N}$ in group after genotyping. Allelic $\mathrm{p}$ : $\mathrm{p}$ value in

475 an allelic genetic model. Dom p: p value in a dominant genetic model of inheritance. OR:

476 odds ratio in an allelic genetic model. CI: confidence interval.

\begin{tabular}{|c|c|c|c|c|c|c|c|c|c|c|c|c|}
\hline & & \multicolumn{3}{|c|}{ Control } & & \multicolumn{3}{|c|}{ Case } & & & & \\
\hline locus & Gene & AA & $\mathrm{Aa}$ & aa & Total & AA & $\mathrm{Aa}$ & aa & Total & Allelic $p$ & Dom $p$ & $\begin{array}{c}\text { OR } \\
(95 \% \mathrm{CI})\end{array}$ \\
\hline rs842618 & REL & 883 & 231 & 13 & 1075 & 289 & 99 & 7 & 395 & 0.032 & 0.035 & $\begin{array}{c}1.33 \\
(1.02- \\
1.73)\end{array}$ \\
\hline rs842634 & REL & 901 & 218 & 11 & 1130 & 299 & 92 & 6 & 397 & 0.052 & 0.064 & $\begin{array}{c}1.21 \\
(0.72- \\
2.0) \\
\end{array}$ \\
\hline
\end{tabular}


medRxiv preprint doi: https://doi.org/10.1101/2021.03.03.21252797; this version posted March 6, 2021. The copyright holder for this preprint (which was not certified by peer review) is the author/funder, who has granted medRxiv a license to display the preprint in perpetuity. It is made available under a CC-BY-NC-ND 4.0 International license.

26

Table 2. Association of SNPs with pediatric TB in South Africa. Number of

481 individuals with major homozygous (AA), heterozygous (Aa), and minor homozygous

482 (aa) genotypes described. Allelic p: $p$ value in an allelic genetic model. Dom p: $p$ value in

483 a dominant genetic model by logistic regression with adjustment for ancestry and

484 gender. OR: odds ratio; CI: confidence interval. * adjusted for ethnicity and gender by

485 logistic regression.

\begin{tabular}{|c|c|c|c|c|c|c|c|c|c|c|c|c|}
\hline & & \multicolumn{3}{|c|}{ Control } & & \multicolumn{3}{|c|}{ Case } & & & & \\
\hline locus & Gene & $\mathrm{AA}$ & $\mathrm{Aa}$ & aa & Total & AA & $\mathrm{Aa}$ & aa & Total & $\begin{array}{c}\text { Allelic } \\
\mathrm{p}\end{array}$ & Dom $p$ & $\begin{array}{c}\text { OR }(95 \% \\
\quad \text { CI })\end{array}$ \\
\hline rs11130215 & BHLHE40 & 99 & 169 & 65 & 333 & 78 & 67 & 25 & 170 & 0.001 & $3.3 \times 10^{-4}$ & $\begin{array}{c}0.5(0.33- \\
0.75\end{array}$ \\
\hline & & & & & & & & & & & $0.012^{*}$ & $\begin{array}{c}0.56(0.28 \\
-0.87)^{*} \\
\end{array}$ \\
\hline rs4496464 & BHLHE40 & 158 & 141 & 35 & 334 & 86 & 66 & 17 & 169 & 0.51 & 0.48 & $\begin{array}{c}1.21(0.72- \\
2.0)\end{array}$ \\
\hline & & & & & & & & & & & $0.39 *$ & $\begin{array}{c}1.30(0.71- \\
2.4)^{*}\end{array}$ \\
\hline
\end{tabular}

486

487 
medRxiv preprint doi: https://doi.org/10.1101/2021.03.03.21252797; this version posted March 6, 2021. The copyright holder for this preprint (which was not certified by peer review) is the author/funder, who has granted medRxiv a license to display the preprint in perpetuity. It is made available under a CC-BY-NC-ND 4.0 International license .

27

\section{References}

1. Mangtani P, Abubakar I, Ariti C, Beynon R, Pimpin L, Fine PE, Rodrigues LC, Smith PG, Lipman M, Whiting PF, Sterne JA. Protection by BCG vaccine against tuberculosis: a systematic review of randomized controlled trials. Clin Infect Dis 2014; 58: 470-480.

2. Sable SB, Posey JE, Scriba TJ. Tuberculosis Vaccine Development: Progress in Clinical Evaluation. Clin Microbiol Rev 2019; 33.

3. Abel L, Fellay J, Haas DW, Schurr E, Srikrishna G, Urbanowski M, Chaturvedi N, Srinivasan S, Johnson DH, Bishai WR. Genetics of human susceptibility to active and latent tuberculosis: present knowledge and future perspectives. The Lancet infectious diseases 2018; 18: e64-e75.

4. Abel L, El-Baghdadi J, Bousfiha AA, Casanova JL, Schurr E. Human genetics of tuberculosis: a long and winding road. Philosophical transactions of the Royal Society of London Series B, Biological sciences 2014; 369: 20130428.

5. Casanova J-L, Abel L. Genetic Dissection of Immunity to Tuberculosis: The Human Model. Annu Rev Immunol 2002; 20: 581-620.

6. Thye T, Owusu-Dabo E, Vannberg FO, van Crevel R, Curtis J, Sahiratmadja E, Balabanova Y, Ehmen C, Muntau B, Ruge G, Sievertsen J, Gyapong J, Nikolayevskyy V, Hill PC, Sirugo G, Drobniewski F, van de Vosse E, Newport M, Alisjahbana B, Nejentsev S, Ottenhoff TH, Hill AV, Horstmann RD, Meyer CG. Common variants at $11 \mathrm{p} 13$ are associated with susceptibility to tuberculosis. Nat Genet 2012; 44: 257-259.

7. Curtis J, Luo Y, Zenner HL, Cuchet-Lourenco D, Wu C, Lo K, Maes M, Alisaac A, Stebbings E, Liu JZ, Kopanitsa L, Ignatyeva O, Balabanova Y, Nikolayevskyy V, Baessmann I, Thye T, Meyer CG, Nurnberg P, Horstmann RD, Drobniewski F, Plagnol V, Barrett JC, Nejentsev S. Susceptibility to tuberculosis is associated with variants in the ASAP1 gene encoding a regulator of dendritic cell migration. Nat Genet 2015; 47: 523-527.

8. Luo Y, Suliman S, Asgari S, Amariuta T, Baglaenko Y, Martinez-Bonet M, Ishigaki K, Gutierrez-Arcelus M, Calderon R, Lecca L, Leon SR, Jimenez J, Yataco R, Contreras C, Galea JT, Becerra M, Nejentsev S, Nigrovic PA, Moody DB, Murray $\mathrm{MB}$, Raychaudhuri S. Early progression to active tuberculosis is a highly heritable trait driven by 3q23 in Peruvians. Nat Commun 2019; 10: 3765.

9. Koeken V, Verrall AJ, Ardiansyah E, Apriani L, Dos Santos JC, Kumar V, Alisjahbana B, Hill PC, Joosten LAB, van Crevel R, van Laarhoven A. IL-32 and its splice variants are associated with protection against Mycobacterium tuberculosis infection and skewing of Th1/Th17 cytokines. J Leukoc Biol 2020; 107: 113-118.

10. Png E, Alisjahbana B, Sahiratmadja E, Marzuki S, Nelwan R, Balabanova Y, Nikolayevskyy V, Drobniewski F, Nejentsev S, Adnan I, van de Vosse E, Hibberd ML, van Crevel R, Ottenhoff TH, Seielstad M. A genome wide association study of pulmonary tuberculosis susceptibility in Indonesians. BMC Med Genet 2012; 13: 5 .

11. Caws M, Thwaites G, Dunstan S, Hawn TR, Lan NT, Thuong NT, Stepniewska K, Huyen MN, Bang ND, Loc TH, Gagneux S, van Soolingen D, Kremer K, van der Sande M, Small P, Anh PT, Chinh NT, Quy HT, Duyen NT, Tho DQ, Hieu NT, 
medRxiv preprint doi: https://doi.org/10.1101/2021.03.03.21252797; this version posted March 6, 2021. The copyright holder for this preprint (which was not certified by peer review) is the author/funder, who has granted medRxiv a license to display the preprint in perpetuity. It is made available under a CC-BY-NC-ND 4.0 International license .

28

Torok E, Hien TT, Dung NH, Nhu NT, Duy PM, van Vinh Chau N, Farrar J. The influence of host and bacterial genotype on the development of disseminated disease with Mycobacterium tuberculosis. PLoS Pathog 2008; 4: e1000034.

12. Shah JA, Vary JC, Chau TT, Bang ND, Yen NT, Farrar JJ, Dunstan SJ, Hawn TR. Human TOLLIP Regulates TLR2 and TLR4 Signaling and Its Polymorphisms Are Associated with Susceptibility to Tuberculosis. Journal of immunology 2012; 189: 1737-1746.

13. Jepson A, Fowler A, Banya W, Singh M, Bennett S, Whittle H, Hill AV. Genetic regulation of acquired immune responses to antigens of Mycobacterium tuberculosis: a study of twins in West Africa. Infect Immun 2001; 69: 3989-3994.

14. Cobat A, Hoal EG, Gallant CJ, Simkin L, Black GF, Stanley K, Jais JP, Yu TH, Boland-Auge A, Grange G, Delacourt C, van Helden P, Casanova JL, Abel L, Alcais A, Schurr E. Identification of a major locus, TNF1, that controls BCGtriggered tumor necrosis factor production by leukocytes in an area hyperendemic for tuberculosis. Clin Infect Dis 2013; 57: 963-970.

15. Cobat A, Poirier C, Hoal E, Boland-Auge A, de La Rocque F, Corrard F, Grange G, Migaud M, Bustamante J, Boisson-Dupuis S, Casanova JL, Schurr E, Alcais A, Delacourt C, Abel L. Tuberculin skin test negativity is under tight genetic control of chromosomal region 11p14-15 in settings with different tuberculosis endemicities. J Infect Dis 2015; 211: 317-321.

16. Sobota RS, Stein CM, Kodaman N, Scheinfeldt LB, Maro I, Wieland-Alter W, Igo RP, Jr., Magohe A, Malone LL, Chervenak K, Hall NB, Modongo C, Zetola N, Matee M, Joloba M, Froment A, Nyambo TB, Moore JH, Scott WK, Lahey T, Boom WH, von Reyn CF, Tishkoff SA, Sirugo G, Williams SM. A Locus at $5 q 33.3$ Confers Resistance to Tuberculosis in Highly Susceptible Individuals. Am J Hum Genet 2016; 98: 514-524.

17. Sobota RS, Stein CM, Kodaman N, Maro I, Wieland-Alter W, Igo RP, Jr., Magohe A, Malone LL, Chervenak K, Hall NB, Matee M, Mayanja-Kizza H, Joloba M, Moore JH, Scott WK, Lahey T, Boom WH, von Reyn CF, Williams SM, Sirugo G. A chromosome 5q31.1 locus associates with tuberculin skin test reactivity in HIVpositive individuals from tuberculosis hyper-endemic regions in east Africa. PLOS Genet 2017; 13: e1006710.

18. Li Y, Oosting M, Smeekens SP, Jaeger M, Aguirre-Gamboa R, Le KTT, Deelen P, Ricano-Ponce I, Schoffelen T, Jansen AFM, Swertz MA, Withoff S, van de Vosse $E$, van Deuren $M$, van de Veerdonk F, Zhernakova $A$, van der Meer JWM, Xavier RJ, Franke L, Joosten LAB, Wijmenga C, Kumar V, Netea MG. A Functional Genomics Approach to Understand Variation in Cytokine Production in Humans. Cell 2016; 167: 1099-1110 e1014.

19. Lee MN, Ye C, Villani AC, Raj T, Li W, Eisenhaure TM, Imboywa SH, Chipendo PI, Ran FA, Slowikowski K, Ward LD, Raddassi K, McCabe C, Lee MH, Frohlich IY, Hafler DA, Kellis M, Raychaudhuri S, Zhang F, Stranger BE, Benoist CO, De Jager PL, Regev A, Hacohen N. Common genetic variants modulate pathogensensing responses in human dendritic cells. Science 2014; 343: 1246980.

20. Roederer M, Quaye L, Mangino M, Beddall MH, Mahnke Y, Chattopadhyay P, Tosi I, Napolitano L, Terranova Barberio M, Menni C, Villanova F, Di Meglio P, Spector TD, Nestle FO. The genetic architecture of the human immune system: a 
medRxiv preprint doi: https://doi.org/10.1101/2021.03.03.21252797; this version posted March 6, 2021. The copyright holder for this preprint (which was not certified by peer review) is the author/funder, who has granted medRxiv a license to display the preprint in perpetuity. It is made available under a CC-BY-NC-ND 4.0 International license .

29

bioresource for autoimmunity and disease pathogenesis. Cell 2015; 161: 387403.

21. Barreiro LB, Tailleux L, Pai AA, Gicquel B, Marioni JC, Gilad Y. Deciphering the genetic architecture of variation in the immune response to \&lt;em\&gt;Mycobacterium tuberculosis\&lt;/em\&gt; infection. Proceedings of the National Academy of Sciences 2012; 109: 1204.

22. Schmiedel BJ, Singh D, Madrigal A, Valdovino-Gonzalez AG, White BM, ZapardielGonzalo J, Ha B, Altay G, Greenbaum JA, McVicker G, Seumois G, Rao A, Kronenberg M, Peters B, Vijayanand P. Impact of Genetic Polymorphisms on Human Immune Cell Gene Expression. Cell 2018; 175: 1701-1715 e1716.

23. Shey MS, Nemes E, Whatney W, de Kock M, Africa H, Barnard C, van Rooyen M, Stone L, Riou C, Kollmann T, Hawn TR, Scriba TJ, Hanekom WA. Maturation of innate responses to mycobacteria over the first nine months of life. J Immunol 2014; 192: 4833-4843.

24. Smolen KK, Cai B, Gelinas L, Fortuno ES, 3rd, Larsen M, Speert DP, Chamekh M, Cooper PJ, Esser M, Marchant A, Kollmann TR. Single-cell analysis of innate cytokine responses to pattern recognition receptor stimulation in children across four continents. J Immunol 2014; 193: 3003-3012.

25. Seshadri C, Thuong NT, Mai NT, Bang ND, Chau TT, Lewinsohn DM, Thwaites GE, Dunstan SJ, Hawn TR. A polymorphism in human MR1 is associated with mRNA expression and susceptibility to tuberculosis. Genes Immun 2017; 18: 8-14.

26. Pulendran B. The varieties of immunological experience: of pathogens, stress, and dendritic cells. Annu Rev Immunol 2015; 33: 563-606.

27. Tian T, Woodworth J, Skold M, Behar SM. In vivo depletion of CD11C+ cells delays the CD4+ T cell response to Mycobacterium tuberculosis and exacerbates the outcome of infection. J Immunol 2005; 175: 3268-3272.

28. Rosain J, Kong XF, Martinez-Barricarte R, Oleaga-Quintas C, Ramirez-Alejo N, Markle J, Okada S, Boisson-Dupuis S, Casanova JL, Bustamante J. Mendelian susceptibility to mycobacterial disease: 2014-2018 update. Immunol Cell Biol 2019; 97: 360-367.

29. Notarangelo LD, Bacchetta R, Casanova JL, Su HC. Human inborn errors of immunity: An expanding universe. Sci Immunol 2020; 5.

30. Wu UI, Holland SM. A genetic perspective on granulomatous diseases with an emphasis on mycobacterial infections. Semin Immunopathol 2016; 38: 199-212.

31. Chen Y, Sharma S, Assis PA, Jiang Z, Elling R, Olive AJ, Hang S, Bernier J, Huh JR, Sassetti CM, Knipe DM, Gazzinelli RT, Fitzgerald KA. CNBP controls IL-12 gene transcription and Th1 immunity. J Exp Med 2018; 215: 3136-3150.

32. Moreira-Teixeira L, Redford PS, Stavropoulos E, Ghilardi N, Maynard CL, Weaver CT, Freitas do Rosario AP, Wu X, Langhorne J, O'Garra A. T Cell-Derived IL-10 Impairs Host Resistance to Mycobacterium tuberculosis Infection. J Immunol 2017; 199: 613-623.

33. Pitt JM, Stavropoulos E, Redford PS, Beebe AM, Bancroft GJ, Young DB, O'Garra A. Blockade of IL-10 signaling during bacillus Calmette-Guerin vaccination enhances and sustains Th1, Th17, and innate lymphoid IFN-gamma and IL-17 responses and increases protection to Mycobacterium tuberculosis infection. $J$ Immunol 2012; 189: 4079-4087. 
medRxiv preprint doi: https://doi.org/10.1101/2021.03.03.21252797; this version posted March 6, 2021. The copyright holder for this preprint (which was not certified by peer review) is the author/funder, who has granted medRxiv a license to display the preprint in perpetuity. It is made available under a CC-BY-NC-ND 4.0 International license .

30

34. Huynh JP, Lin CC, Kimmey JM, Jarjour NN, Schwarzkopf EA, Bradstreet TR, Shchukina I, Shpynov O, Weaver CT, Taneja R, Artyomov MN, Edelson BT, Stallings CL. Bhlhe40 is an essential repressor of IL-10 during Mycobacterium tuberculosis infection. J Exp Med 2018; 215: 1823-1838.

35. Kagina BM, Abel B, Bowmaker M, Scriba TJ, Gelderbloem S, Smit E, Erasmus M, Nene N, Walzl G, Black G, Hussey GD, Hesseling AC, Hanekom WA. Delaying $B C G$ vaccination from birth to 10 weeks of age may result in an enhanced memory CD4 T cell response. Vaccine 2009; 27: 5488-5495.

36. Kagina BM, Abel B, Scriba TJ, Hughes EJ, Keyser A, Soares A, Gamieldien H, Sidibana M, Hatherill M, Gelderbloem S, Mahomed H, Hawkridge A, Hussey G, Kaplan G, Hanekom WA. Specific T cell frequency and cytokine expression profile do not correlate with protection against tuberculosis after bacillus Calmette-Guerin vaccination of newborns. American journal of respiratory and critical care medicine 2010; 182: 1073-1079.

37. Shah JA, Musvosvi M, Shey M, Horne DJ, Wells RD, Peterson GJ, Cox JS, Daya M, Hoal EG, Lin L, Gottardo R, Hanekom WA, Scriba TJ, Hatherill M, Hawn TR. A Functional TOLLIP Variant is Associated with BCG-Specific Immune Responses and Tuberculosis. Am J Respir Crit Care Med 2017.

38. Khor CC, Do T, Jia H, Nakano M, George R, Abu-Amero K, Duvesh R, Chen LJ, Li Z, Nongpiur ME, Perera SA, Qiao C, Wong HT, Sakai H, Barbosa de Melo M, Lee MC, Chan AS, Azhany Y, Dao TL, Ikeda Y, Perez-Grossmann RA, Zarnowski T, Day AC, Jonas JB, Tam PO, Tran TA, Ayub H, Akhtar F, Micheal S, Chew PT, Aljasim LA, Dada T, Luu TT, Awadalla MS, Kitnarong N, Wanichwecharungruang B, Aung YY, Mohamed-Noor J, Vijayan S, Sarangapani S, Husain R, Jap A, Baskaran M, Goh D, Su DH, Wang H, Yong VK, Yip LW, Trinh TB, Makornwattana M, Nguyen TT, Leuenberger EU, Park KH, Wiyogo WA, Kumar RS, Tello C, Kurimoto Y, Thapa SS, Pathanapitoon K, Salmon JF, Sohn YH, Fea A, Ozaki M, Lai JS, Tantisevi V, Khaing CC, Mizoguchi T, Nakano S, Kim CY, Tang G, Fan S, Wu R, Meng H, Nguyen TT, Tran TD, Ueno M, Martinez JM, Ramli N, Aung YM, Reyes RD, Vernon SA, Fang SK, Xie Z, Chen XY, Foo JN, Sim KS, Wong TT, Quek DT, Venkatesh R, Kavitha S, Krishnadas SR, Soumittra N, Shantha B, Lim BA, Ogle J, de Vasconcellos JP, Costa VP, Abe RY, de Souza BB, Sng CC, Aquino MC, Kosior-Jarecka E, Fong GB, Tamanaja VC, Fujita R, Jiang Y, Waseem N, Low S, Pham HN, Al-Shahwan S, Craven ER, Khan MI, Dada R, Mohanty K, Faiq MA, Hewitt AW, Burdon KP, Gan $\mathrm{EH}$, Prutthipongsit A, Patthanathamrongkasem T, Catacutan MA, Felarca IR, Liao CS, Rusmayani E, Istiantoro VW, Consolandi G, Pignata G, Lavia C, Rojanapongpun $\mathrm{P}$, Mangkornkanokpong L, Chansangpetch S, Chan JC, Choy BN, Shum JW, Than HM, Oo KT, Han AT, Yong VH, Ng XY, Goh SR, Chong YF, Hibberd ML, Seielstad M, Png E, Dunstan SJ, Chau NV, Bei J, Zeng YX, Karkey A, Basnyat B, Pasutto F, Paoli D, Frezzotti P, Wang JJ, Mitchell P, Fingert JH, Allingham RR, Hauser MA, Lim ST, Chew SH, Ebstein RP, Sakuntabhai A, Park KH, Ahn J, Boland G, Snippe H, Stead R, Quino R, Zaw SN, Lukasik U, Shetty R, Zahari M, Bae HW, Oo NL, Kubota T, Manassakorn A, Ho WL, Dallorto L, Hwang YH, Kiire CA, Kuroda M, Djamal ZE, Peregrino JI, Ghosh A, Jeoung JW, Hoan TS, Srisamran N, Sandragasu T, Set SH, Doan VH, Bhattacharya SS, Ho 
medRxiv preprint doi: https://doi.org/10.1101/2021.03.03.21252797; this version posted March 6, 2021. The copyright holder for this preprint (which was not certified by peer review) is the author/funder, who has granted medRxiv a license to display the preprint in perpetuity. It is made available under a CC-BY-NC-ND 4.0 International license .

31

672

673

674

675

676

677

678

679

680

681

682

683

684

685

686

687

688

689

690

691

692

693

694

695

696

697

698

699

700

701

702

703

704

705

706

707

708

709

710

711

712

713

714

715

716

CL, Tan DT, Sihota R, Loon SC, Mori K, Kinoshita S, Hollander Al, Qamar R, Wang YX, Teo YY, Tai ES, Hartleben-Matkin C, Lozano-Giral D, Saw SM, Cheng CY, Zenteno JC, Pang CP, Bui HT, Hee O, Craig JE, Edward DP, Yonahara M, Neto JM, Guevara-Fujita ML, Xu L, Ritch R, Liza-Sharmini AT, Wong TY, AlObeidan S, Do NH, Sundaresan P, Tham CC, Foster PJ, Vijaya L, Tashiro K, Vithana EN, Wang N, Aung T. Genome-wide association study identifies five new susceptibility loci for primary angle closure glaucoma. Nat Genet 2016; 48: 556562.

39. Dunstan SJ, Hue NT, Han B, Li Z, Tram TTB, Sim KS, Parry CM, Chinh NT, Vinh H, Lan NPH, Thieu NTV, Vinh PV, Koirala S, Dongol S, Arjyal A, Karkey A, Shilpakar O, Dolecek C, Foo JN, Phuong LT, Lanh MN, Do T, Aung T, Hon DN, Teo YY, Hibberd ML, Anders KL, Okada Y, Raychaudhuri S, Simmons CP, Baker S, de Bakker PIW, Basnyat B, Hien TT, Farrar JJ, Khor CC. Variation at HLADRB1 is associated with resistance to enteric fever. Nature Genetics 2014; 46: 1333-1336.

40. Bustamante J, Boisson-Dupuis S, Abel L, Casanova JL. Mendelian susceptibility to mycobacterial disease: genetic, immunological, and clinical features of inborn errors of IFN-gamma immunity. Semin Immunol 2014; 26: 454-470.

41. Mangino M, Roederer M, Beddall MH, Nestle FO, Spector TD. Innate and adaptive immune traits are differentially affected by genetic and environmental factors. Nature Communications 2017; 8: 13850.

42. Redford PS, Murray PJ, O'Garra A. The role of IL-10 in immune regulation during M. tuberculosis infection. Mucosal Immunol 2011; 4: 261-270.

43. Groux H, Bigler M, de Vries JE, Roncarolo MG. Interleukin-10 induces a long-term antigen-specific anergic state in human CD4+ T cells. J Exp Med 1996; 184: 1929.

44. Shafiani S, Dinh C, Ertelt JM, Moguche AO, Siddiqui I, Smigiel KS, Sharma P, Campbell DJ, Way SS, Urdahl KB. Pathogen-specific Treg cells expand early during mycobacterium tuberculosis infection but are later eliminated in response to Interleukin-12. Immunity 2013; 38: 1261-1270.

45. Sakai S, Kauffman KD, Sallin MA, Sharpe AH, Young HA, Ganusov VV, Barber DL. CD4 T Cell-Derived IFN-gamma Plays a Minimal Role in Control of Pulmonary Mycobacterium tuberculosis Infection and Must Be Actively Repressed by PD-1 to Prevent Lethal Disease. PLoS Pathog 2016; 12: e1005667.

46. Lin CC, Bradstreet TR, Schwarzkopf EA, Sim J, Carrero JA, Chou C, Cook LE, Egawa T, Taneja R, Murphy TL, Russell JH, Edelson BT. Bhlhe40 controls cytokine production by $T$ cells and is essential for pathogenicity in autoimmune neuroinflammation. Nat Commun 2014; 5: 3551.

47. Ip WKE, Hoshi N, Shouval DS, Snapper S, Medzhitov R. Anti-inflammatory effect of IL-10 mediated by metabolic reprogramming of macrophages. Science 2017; 356: 513-519.

48. Tobin DM, Vary JC, Jr., Ray JP, Walsh GS, Dunstan SJ, Bang ND, Hagge DA, Khadge S, King MC, Hawn TR, Moens CB, Ramakrishnan L. The Ita4h locus modulates susceptibility to mycobacterial infection in zebrafish and humans. Cell 2010; 140: 717-730. 
medRxiv preprint doi: https://doi.org/10.1101/2021.03.03.21252797; this version posted March 6, 2021. The copyright holder for this preprint (which was not certified by peer review) is the author/funder, who has granted medRxiv a license to display the preprint in perpetuity. It is made available under a CC-BY-NC-ND 4.0 International license.

32

49. Mahnke YD, Greenwald JH, DerSimonian R, Roby G, Antonelli LR, Sher A, Roederer M, Sereti I. Selective expansion of polyfunctional pathogen-specific CD4(+) T cells in HIV-1-infected patients with immune reconstitution inflammatory syndrome. Blood 2012; 119: 3105-3112. Heterogeneity of intracellular cytokine synthesis at the single-cell level in polarized T helper 1 and T helper 2 populations. J Exp Med 1995; 182: 13571367.

51. Roca FJ, Whitworth LJ, Redmond S, Jones AA, Ramakrishnan L. TNF Induces Pathogenic Programmed Macrophage Necrosis in Tuberculosis through a Mitochondrial-Lysosomal-Endoplasmic Reticulum Circuit. Cell 2019; 178: 13441361 e1311. 

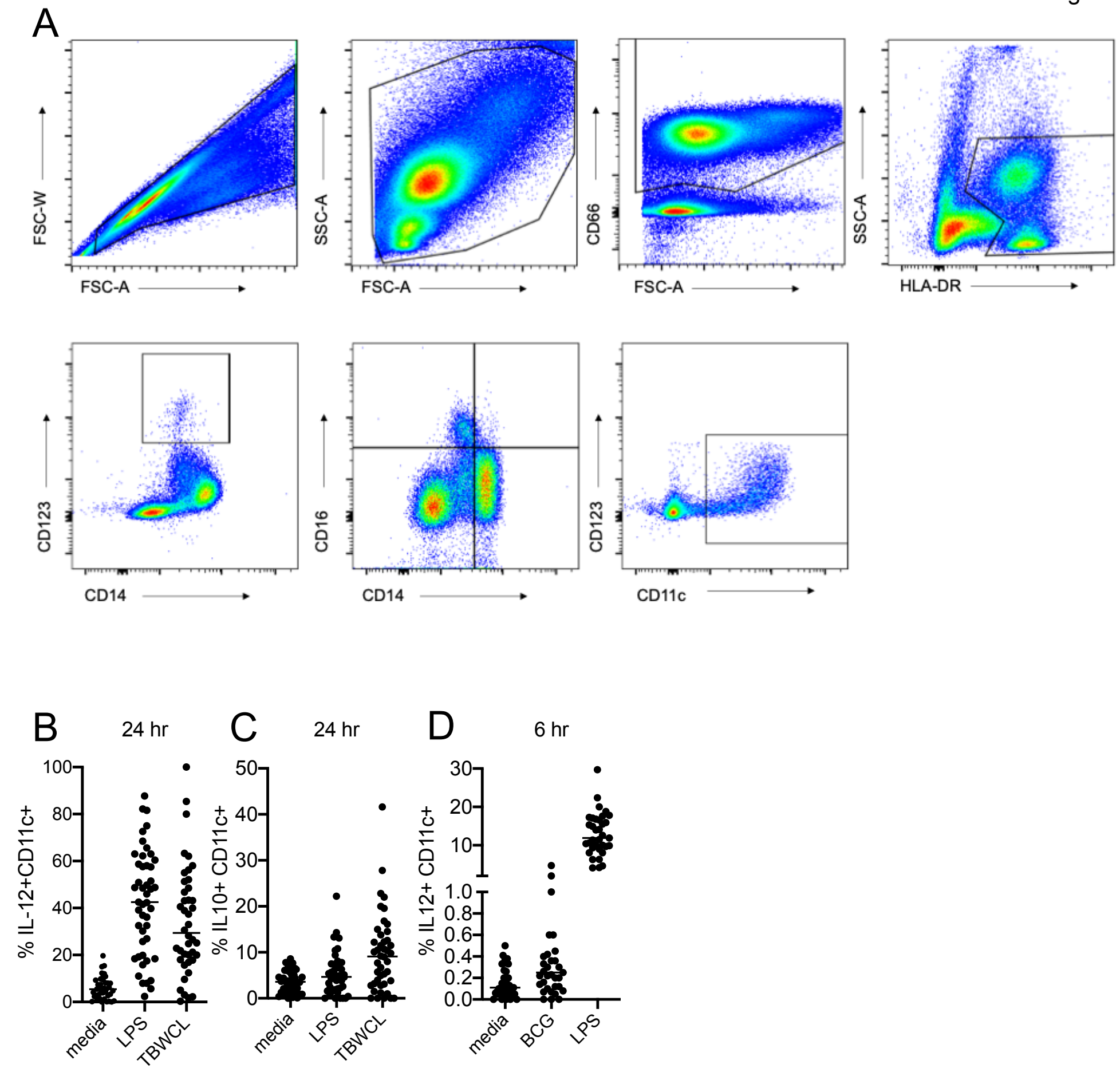
A TBWCL

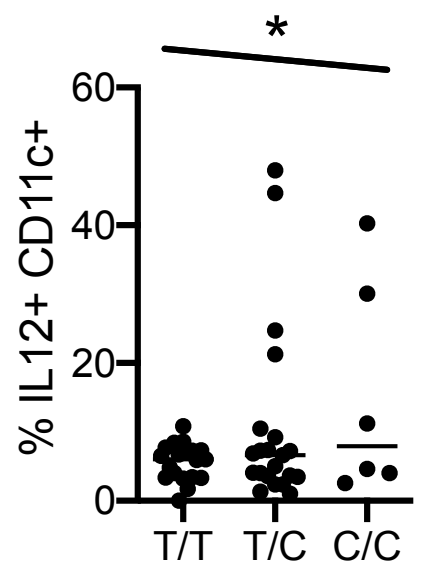

rs842634
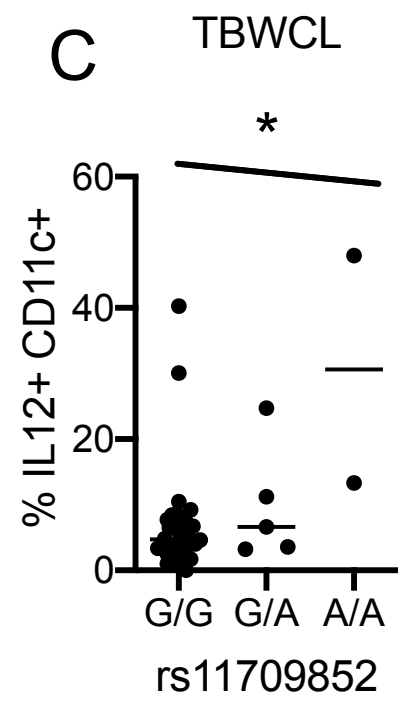

B

LPS

Figure 2 
Figure 3

A BCG

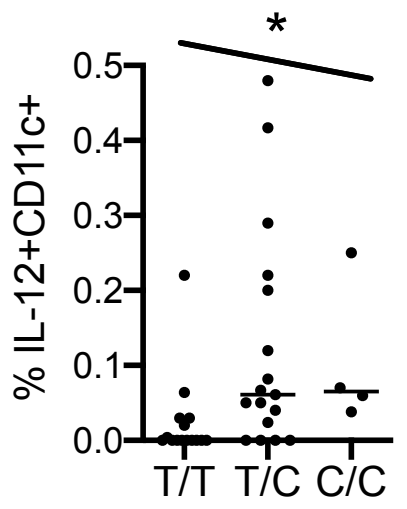

rs842634

C
BCG

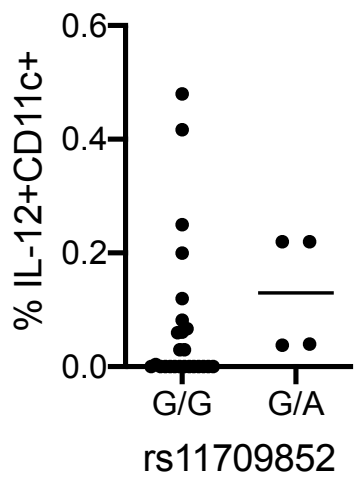

B LPS

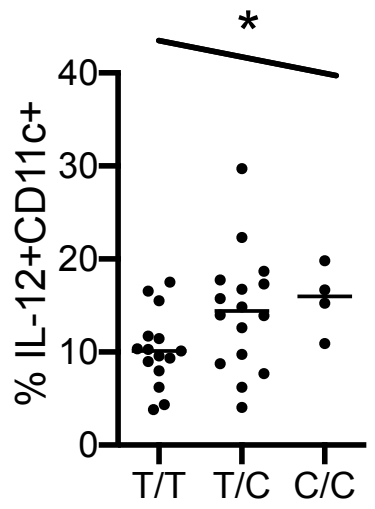

rs842634

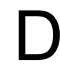

LPS
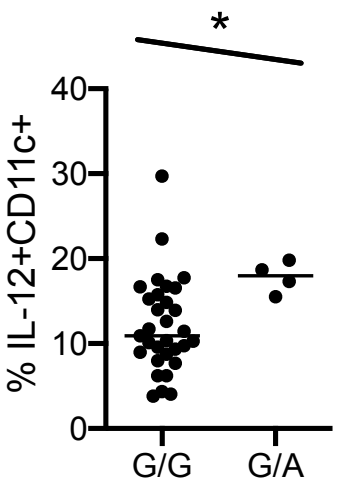

rs11709852 
A TBWCL

B LPS

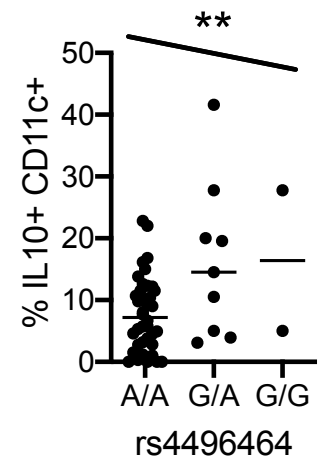

E TBWCL

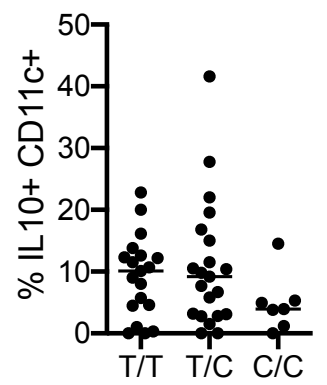

rs842634

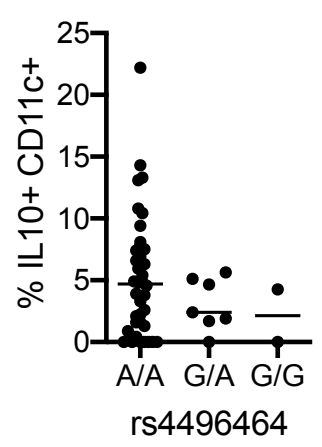

F LPS

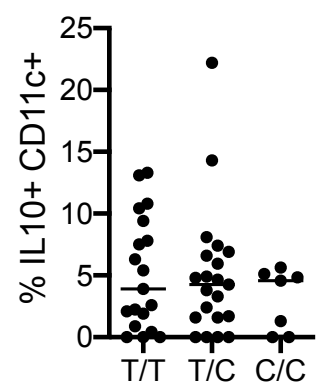

rs842634

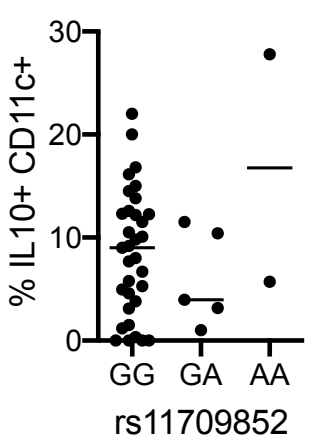

G TBWCL

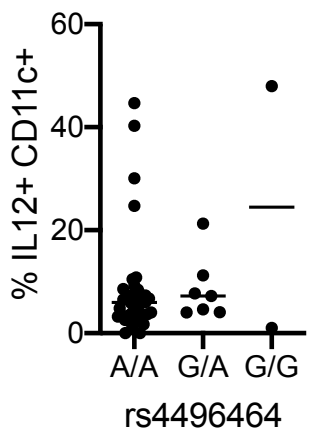

Figure 4

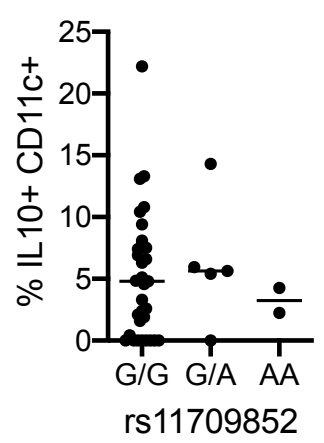

H LPS

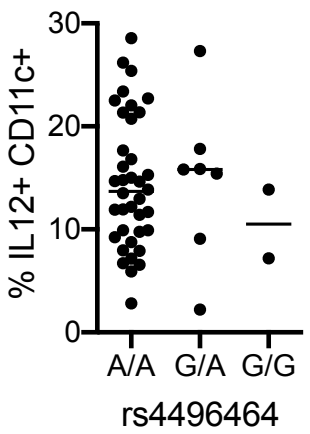




\section{Figure 5 \\ *}

ఫర 0.15

N

ত

읃 $0.10-$

$\varangle$

.
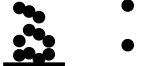

0

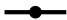

\%

$\varepsilon$

$0.05-$

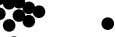

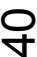

0

1

(1)

$\frac{c}{\bar{c}}$

$0.00 ـ /$ T/T

A/A G/A G/G

rs4496464 
Figure 6

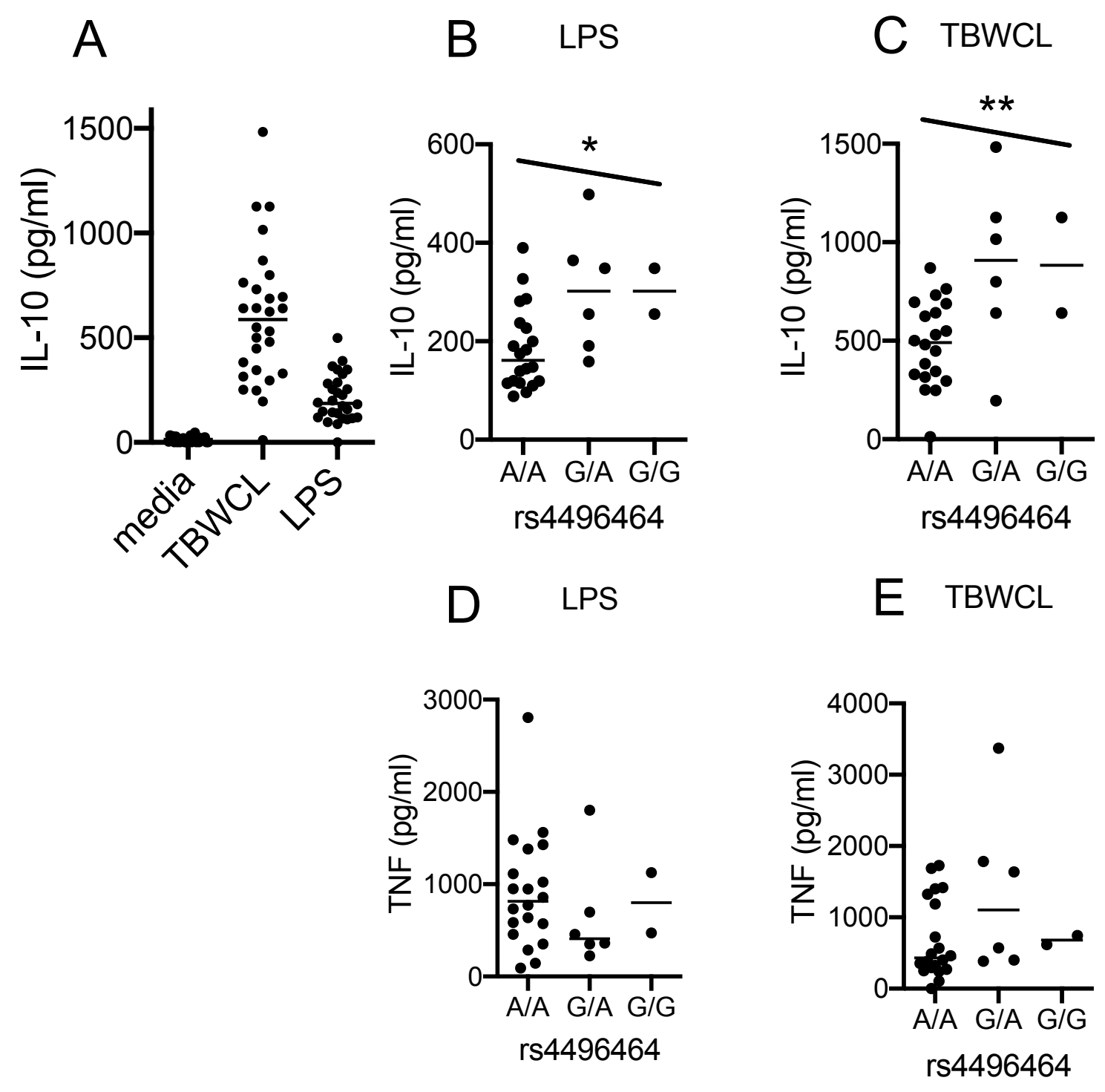




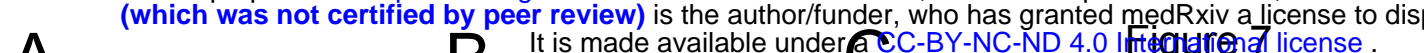
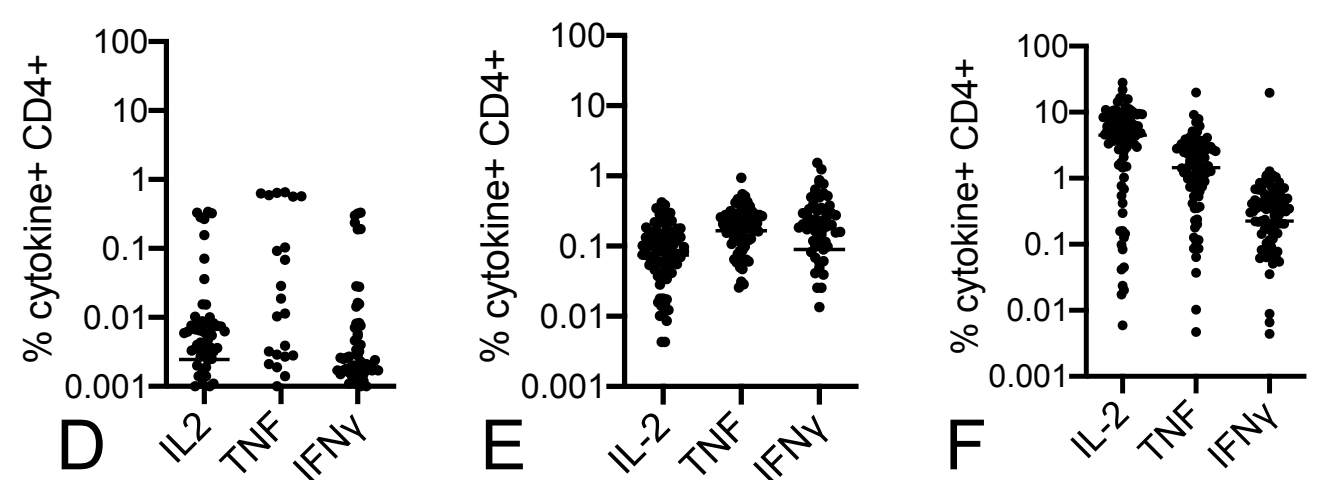

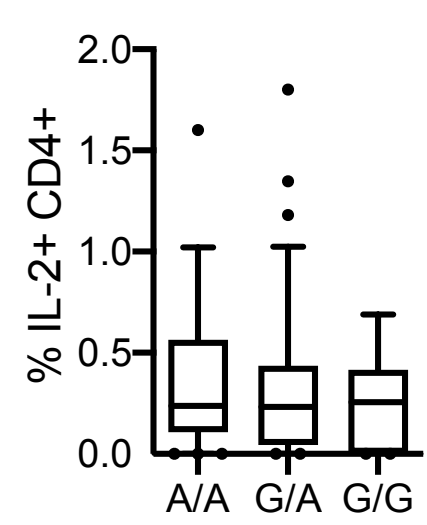

rs4496464

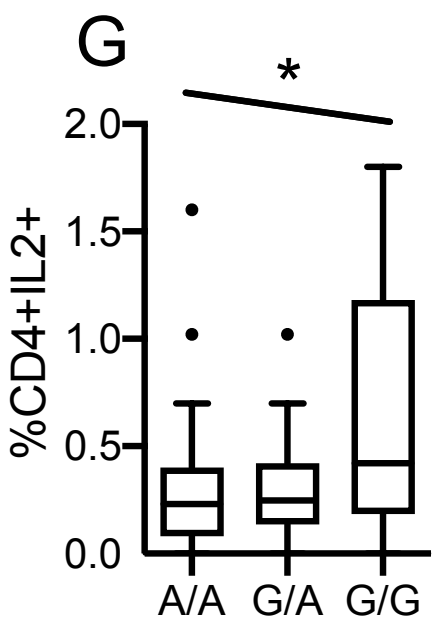

rs11130215

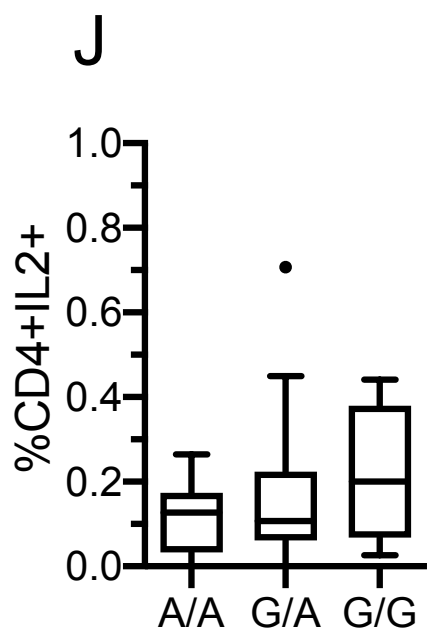

rs11130215

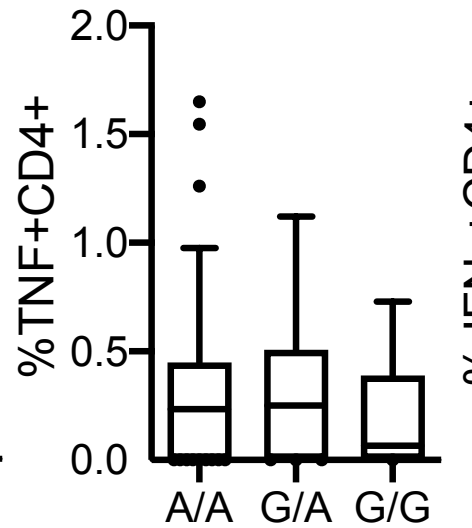

rs4496464
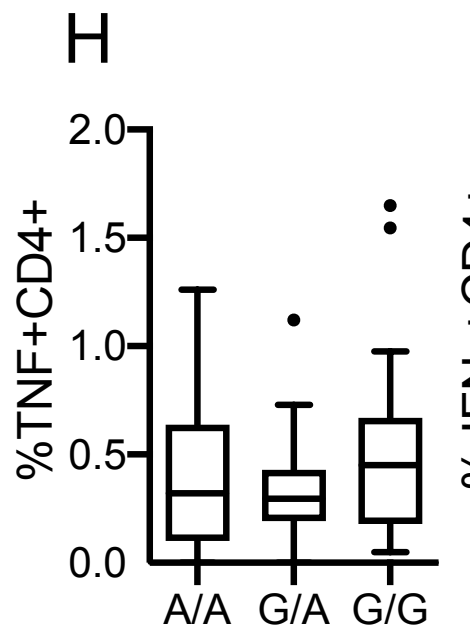

rs11130215

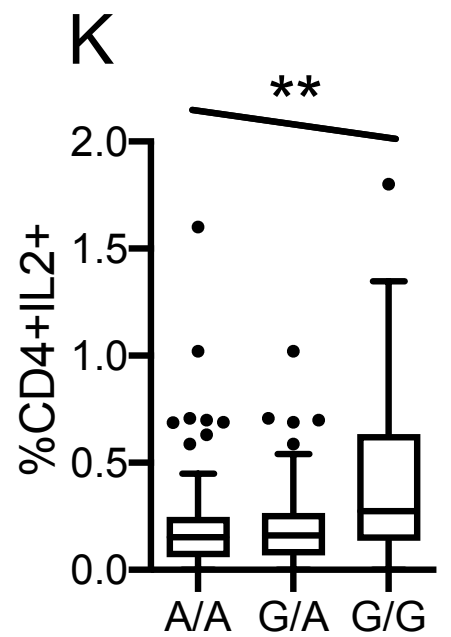

rs11130215 